\title{
"Have you been offended?" Holocaust Memory in the Channel Islands at HMD 70
}

Dr Gilly Carr,

Senior Lecturer in Archaeology,

Trumpington Street,

St Catharine's College,

Cambridge,

CB2 1RL.

Email: gcc20@cam.ac.uk

Tel: 07790528424

Affiliation: (University of Cambridge Institute of Continuing Education)

Dr Gilly Carr is a Senior Lecturer in Archaeology at the University of Cambridge Institute of Continuing Education. She is also a Fellow and Director of Studies at St Catharine's College. Gilly works in the field of Heritage Studies and Conflict Archaeology and regularly speaks at international conferences. Her recent publications include Heritage and Memory of War: Responses from small islands (co-edited, Routledge 2015); Legacies of Occupation: Heritage, Memory and Archaeology in the Channel Islands (Springer 2014); and Protest, Defiance and Resistance in the Channel Islands: German Occupation 1940-1945 (coauthored, Bloomsbury Academic 2014).

Acknowledgements

The author would like to thank Freddie Cohen, Elis Bebb, Sir de Vic Carey and Sir Philip Bailhache for interviews collected during my fieldwork. I would also like to thank the Holocaust Memorial Day committee in Jersey for inviting me to the island to speak at the HMD 70.

MS length: 10,573, including endnotes.

Revision submitted 27 September 2015: 11,001 words, including endnotes.

Disclosure statement: I have no financial interest and will receive no financial benefit arising from this research. 
“Have you been offended?" Holocaust Memory in the Channel Islands at HMD 70

\begin{abstract}
The Channel Islands have experienced great difficulty in coming to terms with the Holocaust given the implication of the local authorities in the registration of the islands' Jewish population during the German occupation. While the situation in Jersey began to change in the 1990s due to the actions of the island's leadership, the issue is still taboo in Guernsey today. Taking a historical approach, this paper addresses the power of that taboo at the time of Holocaust Memorial Day 2015, proposing the concept of the "incremental memory event" as a way of understanding the differences in memory in both islands.
\end{abstract}

Key words: Incremental Memory Event, Holocaust Memorial Day, HMD 70, Channel Islands, social media, taboo.

\title{
Introduction
}

Not all places in Europe have come to terms with the Holocaust and the role of their wartime authorities in its implementation. Open and frank public discussion is not always possible and has not taken place everywhere. In the Channel Islands, the Holocaust has proved to be the final wartime taboo. While the largest of the five islands, Jersey, now has a strong and open Holocaust Memorial Day (HMD) culture, this is not the case in the second-largest Channel Island of Guernsey. Such is the strength of the taboo here that even outsiders and recent incomers are aware of its force and find it hard to bring discussion to the stage (both metaphorically and literally speaking, as will be shown).

This paper begins by discussing local understandings of the Holocaust and those who are remembered on HMD. It will then chart the long-term attitudes towards the memory of the Channel Islands' Jews and political prisoners before exploring the nature of the former taboo in Jersey, examining how it was removed in that island. It then seeks to understand why and how it remains cemented so firmly in place in Guernsey, examining the furore in local social media in the lead up to HMD 70, the seventieth anniversary of the liberation of Auschwitz in January 2015. It concludes by examining what has been and remains to be done to counteract or lift the force of the taboo and when, if ever, this might take place. Theoretically, this paper proposes the concept of the "incremental memory event", building upon and adapting the original concept of the "memory event" put forward by Alexander Etkind. ${ }^{1}$

While the Channel Islands are inward-looking, they have long been influenced very strongly by the British war narrative. Berger suggested that British memorial culture around the Holocaust developed late compared to other countries because the Second World War was perceived as something "fought on the continent by continentals." 2 To this we might suggest that the Holocaust is likely to have been seen, in the UK, as something that happened only to people caught in occupied territories, noting that mainland Britain was not occupied. This, of course, ignores the Channel Islands' experience.

The occupation of the Channel Islands was similar in several respects to that of other countries in Western Europe. The Jewish population was persecuted and deported; ${ }^{3}$ those who committed acts of resistance were imprisoned locally or deported to Nazi prisons and concentration camps on the continent; ${ }^{4}$ and foreign labourers were imported to the islands to build the concrete bunkers of the Atlantic Wall, ${ }^{5}$ and for the most part were treated appallingly. Despite these examples among many others, the Channel Islands' war narrative is dominated by what Paul Sanders terms the "Churchillian paradigm" - the "blood, toil and 
tears" of sublime and unwavering steadfastness in the face of adversity." "It is a narrative which states that "the British were not a nation of victims, but of victors." John Ramsden has also identified this "Churchillian interpretation" or myth of the war, ${ }^{8}$ which Mark Connelly suggests may even have its roots in the Great War. ${ }^{9}$

Sanders further states that the islands were subject to pressure to adopt this narrative so that the occupation could be viewed as "no more than a parenthesis within a long, illustrious history of British rule." 10 The islands' arch Euro-scepticism and intimately interwoven cultural and business affairs with Britain have also exacerbated the lack of influence from Europe. As the particular institutional and constitutional set-up in the islands was capable of withstanding the occupation and surviving, unchallenged, into the post-war period, Sanders further argues that it is this which has prevented rapprochement of Channel Islands and European war memory. ${ }^{11}$ And while these explanations go a long way to explaining the memorial culture in the Channel Islands, there are further factors in place which stand in the way of discussing the Holocaust, as will be explored here.

\section{Local understandings of the Holocaust}

The Holocaust was not something which intruded into the war narrative of the Channel Islands for the first fifty years after liberation. Today, it is understood locally, in Jersey at least, as something which affected the lives of two different groups of people: the islands' Jewish communities and those deported for acts of resistance. In Guernsey only the Jewish community are remembered on Holocaust Memorial Day, but this changed in 2015. In reality, there is a third group in the islands who were affected by the Holocaust: the foreign labourers of the Organisation Todt, a paramilitary engineering organisation. By May 1943, 16,000 of these men and women were present in the islands. ${ }^{12}$ Some of these people were Jewish $^{13}$ and had come from or were sent back to concentration camps, but they are not remembered on HMD. This is the case even though an SS-run concentration camp existed in Alderney along with at least 4 other slave labour camps in that island, and slave and forced labour camps existed in Jersey and Guernsey too. Instead, the foreign labourers are remembered on Liberation Day in Jersey and Remembrance Sunday in Guernsey, which means that their memory is disassociated with the Holocaust.

First and foremost, the Holocaust impacted the islands' Jewish communities, who are locally perceived to comprise two groups: immigrants to the islands of the 1930s (those fleeing Nazi persecution elsewhere in Europe) and "British Jews" (i.e. both those who had been resident in the islands for generations, and the newly arrived who married local men which gave them British citizenship.) This group were among those targeted for deportation to civilian internment camps in Germany in February 1943 alongside former officers in the British army and "undesirables", i.e. those previously imprisoned for resistance offences. All of the "British Jews" in this category survived and are not locally perceived to have been treated differently to others given that they were among a wider group of 2,200 islanders deported to civilian internment camps. This is not strictly true; not only would they not have been deported had it not have been for their Jewish identity, but one deportee, John Max Finkelstein, a Romanian Jew, was taken from the male civilian internment camp of Laufen and sent on to Tittmoning, and from there to Weimar, then Buchenwald and, later, Theresienstadt. ${ }^{14} \mathrm{He}$ was not the only civilian deportee who was moved on to a concentration camp. ${ }^{15}$

It is important for the purposes of this paper to explain briefly what happened to the Jewish community of the Channel Islands (or, more precisely, to those "deemed to be Jews"), and to note those who protested against the way that the Jews were treated.

There has been a Jewish community in Jersey since the nineteenth century and a synagogue was built in St Helier in 1842. The majority of the practising Jews resident in Jersey left the 
island before the beginning of the German occupation. ${ }^{16}$ Although no formal Jewish community existed in Guernsey, a number of Jews evacuated from the island in advance of the arrival of the Germans. ${ }^{17}$ During the occupation, nine consecutive anti-Jewish Orders were registered in the Royal Courts between October 1940 and August 1942. These orders included the registration of those "deemed to be Jews", the Aryanization of Jewish businesses, the forced sale of Jewish businesses, a curfew for Jews, and the wearing of the yellow star. ${ }^{18}$

It is worth noting that there were a small number of protests against the orders against the Jews. Of those in positions of authority in local government, we know that the Eighth Order relating to the wearing of the yellow star was not registered in Jersey due to the intervention of Alexander Coutanche, Bailiff of Jersey. ${ }^{19}$ In Guernsey, the eventual delayed arrival of the yellow stars meant that the island's resident Jews had already been deported, rendering them unnecessary. A note exists in the memoirs of Ambrose Sherwill. Sherwill was the Attorney General (and post-war Bailiff) of Guernsey until his removal from office in January 1941, following his return from Cherche-Midi prison in Paris for his role in the sheltering of British commandos. He records that he had not protested against the wearing of the yellow star because he believed that all Jews in the islands had evacuated, and that, in any case, if he had, the Germans "would have been difficult" and registered it themselves, without going through the Royal Court. Sherwill's memoirs are the only source that notes that Jurat ${ }^{20}$ Abraham Lainé, when "called upon to vote on the matter, openly and categorically refused his assent and stated his grave objections to such a measure." 21

In terms of protests by non-elites against the Orders against the Jews, Major Marie Ozanne of the Salvation Army had already shown herself to be outspoken on questions of conscience. Until her death in Guernsey prison in 1943, she wrote a number of letters to the German commandant about the treatment of the foreign forced and slave labourers, the deportation of many of the non-local population to civilian internment camps in Germany, and about the treatment of the Jews. She wrote to the Feldkommandantur on this matter on 26 June 1941, nine days after the Third Order against the Jews was registered in the Royal Court of Guernsey. The Third Order redefined those persons considered to be Jewish and prohibited Jewish-owned businesses from carrying out many economic activities. ${ }^{22}$ Ozanne wrote to the commandant to condemn the persecution of the Jews. Reminding him that they were God's chosen people, and that Jesus himself was a Jew, she wrote that Jesus was "the only one by whom we can inherit eternal life and enter heaven." ${ }^{23}$ This was the only known protest from a religious figure in the Channel Islands, and Ozanne is remembered today with a Blue Plaque $^{24}$ which was attached in 2013 to the house where she lived during the occupation.

In April 1942, three Jewish women were deported from Guernsey to France: Marianne Grunfeld who arrived in the UK from Poland in 1937; Therese Steiner from Austria, who came to the Channel Islands in 1939; and Auguste Spitz, also from Austria, who arrived in 1937. The three women were arrested in Laval in July 1942 and eventually deported to Auschwitz-Birkenau, where they died. Cohen suggests that the only person to protest at the deportation of any of the women (i.e. Marianne Grunfeld), was probably Edward Ogier, her employer. ${ }^{25}$ Reverend Douglas Ord, a Methodist minister, noted in his diary for 18 April 1942 that

a friend [presumably Ogier] stopped me outside Grand Lodge, the Civilkommandantur [sic] to vent his rage and sorrow. He had gone to appeal for a girl employee who is only just within the forbidden degrees of Jewish birth and is to be carried off. The officials listened to the arguments he put but were powerless to resist the inhuman decree of the Nazi Frankenstein. ${ }^{26}$ 
The second group who are locally understood to be affected by the Holocaust are those who suffered in the Nazi prison and concentration camp system: the islands' political prisoners, deported for offences of protest, defiance and resistance against the occupying authorities. It can truthfully be said that the experiences of this group are the least known. While those from Jersey who died, the "Jersey 21", are commemorated on the island's Lighthouse Memorial (figure 1), unveiled in 1996, and the ceremonial and memorial focus on HMD for victims of Nazism, the story of the survivors is little known. The exception to this is Harold Le Druillenec, who testified at the Nuremberg trials and was the only British survivor of Belsen. In Guernsey, the "Guernsey 8", a newly designated group that will be discussed later, has received less publicity. A memorial to these people was unveiled in St Peter Port, the capital town of Guernsey, on 4 May 2015 after campaigning by the author. While their stories are presented in the island's German Occupation Museum, there are errors in some of the information presented because of the lack of knowledge about the final destination or place of death of those who did not return to the islands after the war. On the whole, information presented in Guernsey's occupation museums has come from either local oral testimony or local archives. Rarely has information come from further afield. What is simply not known is that around 250 Channel Islanders were deported for offences against the occupiers, a number calculated for the first time recently. ${ }^{27}$ While a greater number has been estimated by the late Joe Mière, a former political prisoner in Jersey, ${ }^{28}$ this list contains many errors.

INSERT FIGURE 1 HERE: Caption: The Lighthouse Memorial, Jersey. Copyright: Gilly Carr

In the mid-1960s, Channel Islanders who had been sent to Nazi prisons and concentration camps were allowed to apply for a share in the $£ 1 \mathrm{M}$ compensation, along with other UK nationals, from the West German government. Many of the islanders received help in their applications from a former political prisoner from Guernsey, Frank Falla, who acted as an intermediary between the Foreign Office and other islanders. He took on the job because, in his own words, "not one official in Guernsey or Jersey saw that here was a cause which would be helped if it was officially recognised and presented on behalf of those who were uncertain how to go about claiming their due." 29

The testimonies written at that time have been kept as closed Foreign Office files since that date. Falla died in 1983. In 2010, his daughter gave me her father's personal archive. This contained carbon copies of many testimonies. These and their associated files allowed me to calculate that around 100 of those deported applied for compensation. These testimonies alone show that islanders were deported to around 90 different Nazi prisons and concentration camps in France and Germany and further afield. The remaining 150 who did not apply for compensation are likely not to have done so for several reasons. Some would have died before the mid-1960s. Others had emigrated to America, Australia or Canada, lost their British citizenship and, with it, the right to claim compensation. Yet others did not apply because they were not eligible or did not believe that they were eligible; or because they did not want to receive German "blood money" or were simply too proud to apply.

Whatever the reasons for application or non-application, the testimonies are now being returned to tracked-down families where requested, and are beginning to be publicised in the Channel Islands in the Guernsey Press and Jersey Evening Post (for example on August 15, 2014 and January 17, 2015 in the former, and July 11, 2013 in the latter) and will be used in heritage presentation. They will also be published. ${ }^{30}$ For the first time, they are gaining a wider audience and this group is becoming better known. Those who returned to the islands from prisons and camps after the war rarely spoke about their experiences to their families, for fear of transmitting such traumatic experiences to their children. The children also quickly 
learned not to ask questions, thus leading to a "double wall" of silence identified by Dan BarOn. ${ }^{31}$ Some of these testimonies were revealed to a wider public on Holocaust Memorial Day in 2015 , as will be discussed later.

\section{Amnesia and the Holocaust: the first twenty years}

Now that the groups perceived locally to have been affected by the Holocaust have been discussed, it is instructive to examine the way that those deported to Nazi prisons and concentration camps - and the memory of their experiences - was treated between the end of the war and the mid-1960s. Here I will argue that attitudes of political elites towards resisters were mostly negative during and after the occupation; a position that was to prove longlasting and which contributed heavily towards the taboo surrounding discussion of the Holocaust, most especially in Guernsey.

Islanders would have been well aware, during the German occupation, of the Orders against the Jews (which were placed in the local papers), the ill-treatment and desperation of the foreign labourers (who they saw with their own eyes), and the crack-down upon, and disappearance of, friends and neighbours who offended against the occupiers, or who were caught up in high-profile trials designed to scare the rest of the population into meek submission. After the occupation, the three Jewish women deported to Auschwitz did not return to tell their tale, although those who returned from other prisons and concentration camps were often interviewed in the local newspapers. As many of this group returned to poverty, their health temporarily or permanently affected, and with little prospect of working at least in the short term, selling their story was a way of earning money. This was the case with, for example, Julia Barry, who was sent to Ravensbrück (Guernsey Evening Press, July 20, 1945; July 30, 1945; August 17, 1945), and Frank Falla, who survived Frankfurt-on-Main and Naumburg-on-Saale prisons, where many Channel Islanders perished (Jersey Evening Post, July 4, 1945; Guernsey Evening Press, July 2, 1945). The stories emerging in the local papers in the summer of 1945 were soon lost, however, among tales of returning evacuees from the UK, returning deportees from civilian internment camps in Germany, military POWs coming home from their camps in Germany and the Far East, and general news from the continuing war in Japan. The stories of resisters and their experiences in Nazi prisons and concentration camps may stand out to us now, but there is no evidence to suggest that this group stood out among the island communities who had been traumatised through occupation and split through evacuation, deportation or military service. There is little evidence of popular or elite sympathy for resisters who got caught or for their plight either at the time or later. A number of snap-shots taken over a 20 year period will suffice to illustrate the point that acts of resistance were by no means universally perceived to be legitimate by the population as a whole.

The now-infamous speech delivered on 7 August 1940 by the aforementioned Ambrose Sherwill, President of the Controlling Committee in Guernsey, to the States of Deliberation (local parliament), set out the position to be adopted by the island's government towards their occupiers:

May this occupation be a model to the world. On the one hand, tolerance on the part of the military authority, and courtesy and correctness on the part of the occupying forces, and on the other, dignity and courtesy and exemplary behaviour on the part of the civilian population. ${ }^{32}$ 
This meant that the population were supposed to abstain from - and indeed reject - notions of resistance, and to comply with German orders. In fact, Sherwill brought in legislation at the end of July 1940, backdated to the start of the occupation, making "an offence any behaviour by a civilian likely to cause a deterioration in the relations between the occupying forces and the civilian population." ${ }^{33}$ This meant that not only would any act of resistance be punished by the Royal Court as well as the German military court, but also that anyone who got into trouble could not count on help from the local authorities. Thus, any actions which hinted at sabotage or similar were labelled as "stupid and criminal" by the authorities (e.g. The Guernsey Star, March 22, 1941). While the Jersey authorities were less vocal in their condemnation of resistance, their position was to prove much the same.

This stance did not change after the occupation. Those in positions of authority, most especially the Bailiffs, Victor Carey of Guernsey and Alexander Coutanche of Jersey, were knighted. None of those who committed acts of resistance, no matter how patriotic, received any honour, with the exception of a British Empire Medal for Bill Bertram from Jersey, who helped escapees leave the island. Even ten years later, there wasn't even so much as a roll of honour of those who died in Nazi prisons and camps. ${ }^{34}$

In the mid-1960s, when Channel Islanders were able to claim a share of the $£ 1 \mathrm{M}$ compensation given to the British government by the West German government, still nobody in a position of authority in local government offered to help those file a claim who were "victims of Nazi persecution and [had] suffered detention in a concentration camp or comparable institution", as the advertisements for compensation phrased it. ${ }^{35}$

As a survivor of Frankfurt and Naumburg prisons, the destination for many islanders, Frank Falla had taken it upon himself after the war to visit the families in Jersey and Guernsey of islanders who had died to tell them about the demise of their loved ones. He was also the instigator and organiser of annual reunions of men who had survived these prisons with him. Further, he had also been chosen (in place of the still-recuperating Harold Le Druillenec) to represent the Channel Islands at post-war resistance celebrations in 1946, in Vielsalm in Belgium. These were all formative experiences for Falla, and it is likely that he begun to see himself as something of an unofficial spokesperson for Channel Islander resisters from 1946 onwards. Thus, at the time of the compensation claims, Falla "stood by anticipating a local awakening" that never came. "No one raised a finger to help ... So I decided to do my best to find out what it was all about and before long found that I had become a kind of unofficial 'official." "36 While Falla tracked down other eligible islanders through the local papers, and helped them write their testimonies and file their claims, his work did not bring the local support he might have expected. An anonymous letter writer to the editor of the local paper argued that resisters should be last in the queue for compensation because their imprisonment was brought about by their own actions and their behaviour had risked the lives of others (Guernsey Evening Press, September 21, 1964).

Falla was unimpressed by the reception of his efforts in helping islanders get compensation. In his memoirs, he complained that the civil authorities "disowned" resisters "blatently", and "never got around to owning us again." 37 And this was still the situation as the $50^{\text {th }}$ anniversary of liberation drew near in 1995.

\section{The Impervious Membrane of the Taboo, 1945-1995}

The compensation claims of the mid-1960s themselves should have been enough to qualify as a "memory event", as conceptualised by Alexander Etkind. For Etkind, a memory event is "a re-discovery of the past that creates a rupture with its accepted cultural meaning. Memory events are secondary to the historical events that they interpret, usually taking place many years or decades later." They are 
defined temporally, as moments of the transformation of the public sphere, rather than spatially, as fixed locations on national territory ... memory events produce volatile effects that generate secondary waves and aftershocks ... [they are] simultaneously acts and products of memory ... [and] always have their authors and agents initiators or even enthusiasts of memory - who lead the production of these collective events. $^{38}$

Frank Falla, as an agent of memory, had done his best, 20 years after the German occupation, to re-awaken public memory of the suffering of his friends and "fictive kin." 39 As a journalist, Falla was able to get publicity for his cause in the local papers. When compensation was successfully obtained, he ensured that it made front page news on August 23, 1965 in the Guernsey Star and the Guernsey Evening Press. And yet this "event" of compensation did not act as a memory event. While it may have acted as a "rediscovery of the past" for the population, it did not create a "rupture" with its "accepted cultural meaning". Resisters were still trouble makers and "naughty lads [who] stepped out of line with the Germans". As Falla put it, the local authorities had not yet got around to "owning" the resisters. ${ }^{40}$

The Eichmann trial of 1961, just four years earlier, triggered a memory event in relation to understandings of the Holocaust because of its international TV broadcast of testimonies of Jews - the first time that the general public had heard Jewish survivors of the camps, in large numbers, speak these testimonies publicly. The newly recognised identity of the survivor emerged - someone whose new function was to be the "bearer of history", as Wieviorka put it. ${ }^{41}$ Yet audiences in the Channel Islands seemingly drew no parallels between Jews and islanders who suffered in concentration camps. There was, it seems, little sympathy - perhaps for either group. While the Eichmann trial "freed the victims to speak" and "created a social demand for testimonies" - indeed, marked the "advent of the witness," 42 this was not the case everywhere. Rather, it was the period of compensation itself, and the request for testimonies, that gave a voice to camp and prison survivors in the Channel Islands; but their words were seen by Foreign Office officials alone. This was not an opportunity for the (re-)serialisation of testimonies in the local newspapers. The public audience in the Channel Islands was simply not ready yet to face a reminder of the darkest parts of the occupation. They were not to show any willingness in this regard for another thirty years.

Elsewhere the phases of post-war memory of Channel Islanders has been analysed as expressed through heritage in forms such as museum exhibitions, memorials and commemorative ceremonies. While the 1940s and early 1950s were a period of mourning dead soldiers and cleansing the islands of the "taint" of German military hardware, most of the 1950s and 1960s were a period of self-imposed amnesia. In the later 1970s, when the post-war generation had reached adulthood, the islands entered a phase of "occupation nostalgia", which has never entirely faded. From 1995 onwards, we see the beginnings of "remembering" the victims of Nazism ${ }^{43}$ - a whole generation later than in other parts of Western Europe. ${ }^{44}$ Rather than focusing principally on the late cause of the recognition of the Holocaust and the reach of its tendrils to the Channel Islands, which can be explained by the strong influence and impervious membrane of the Churchillian paradigm and the taboo against discussing the Holocaust, I wish to examine how that membrane was punctured in Jersey. It is here that the role of the incremental memory event comes into play. This will lead us towards a better understanding of the un-punctured membrane of memory in Guernsey and the potential impact of the events of 2015.

\section{Puncturing the Taboo and the Incremental Memory Event}


Before we can examine how the taboo surrounding the Holocaust was broken in Jersey, it is necessary to explain why I label the memory of the Holocaust taboo, especially in Guernsey. It is important to preface this information with an appreciation of the nature of the kind of small communities that exist in the Channel Islands. The islands are, in general, conservative and law-abiding places, where those who put their heads above the parapet to speak out against the status quo or seriously criticise local government can quickly find themselves ostracised. In the modern era of the last twenty to twenty-five years - or even longer - it has not been politically expedient for any politician in Guernsey to criticise the actions of the local administration during the German occupation. Although not a polite topic of conversation, it is generally agreed (sotto voce) that Alexander Coutanche of Jersey acquitted himself better than his opposite number in Guernsey because of his age (48 versus Carey's 69 at the start of the occupation), associated energy, and vigilant stance (behind the scenes) in standing up to the occupiers. Despite this, Carey has been beyond local criticism. Even though Jews and political prisoners were deported on his watch, no politician has been able to encourage self reflection of this period of Guernsey's history for one reason: because Victor Carey's grandson, Sir de Vic Carey, became Bailiff himself in 1999. Sir de Vic became an advocate of the Royal Court in 1966, a Deputy in the States of Guernsey (an elected representative of local parliament) from 1976, and has held high office in the island from 1977 onwards, becoming Deputy Bailiff in 1992 and Lieutenant Bailiff in 2005, upon his retirement. This means that for a significant number of decades, no politician has taken it upon themselves, out of respect, to criticise the wartime record of Victor Carey while his grandson, now 75 years old, is still a prominent person in the island. This taboo was also confirmed to me by a former Bailiff of Jersey, who also explained that post-war Guernsey Bailiffs before Sir de Vic had close family links to the occupation administration of the island and similarly had little inclination to encourage examination of occupation consciences.

By 1995, at the time of the fiftieth anniversary of liberation, the Bailiff of Jersey was Philip Bailhache. He was appointed in 1995, knighted in 1996, and retired from office in 2009. Bailhache began to be called upon to unveil memorial plaques and make speeches about victims of Nazism as it was known that he had an interest in the subject and the cause was close to his heart. During his period of office he unveiled a number of these memorials, such as the 1995 political prisoner memorial on the site of the demolished wartime prison, and the 1996 Lighthouse Memorial, which recalled the death of the "Jersey 21" in Nazi prisons and concentration camps, as will be discussed later. An arts project in 2005, at the $60^{\text {th }}$ anniversary of liberation, involved the creation of a "pavement memorial" in St Helier, where moving quotes from victims of Nazism were engraved into a series of paving slabs in the island's capital. Thus, this slow increase in the number of memorials and heritage to victims of Nazi persecution in Jersey has helped to modify the everyday reminders of the occupation years among the island's population. Such was Bailhache's role in this acknowledged change in the island's war narrative during his period of office, that this phenomenon became known as the "Bailhache effect".

Meanwhile, in Guernsey the "Carey effect", as we might term it, was very much in evidence. Even as late as 1990, when Carey held the position of H.M. Procureur (second only to the Deputy Bailiff, who himself is second to the Bailiff), the playwright Julia Pascal was refused a license to perform her play Theresa in Guernsey on the grounds that it was "inappropriate". Based on the life of Austrian Jew, Therese Steiner, who came to Guernsey in 1939, the play highlighted the role of collaboration in the deportation of the island's Jews. Luckhurst declared this ban as an act of "politically motivated censorship" because of the emphasis the play placed on the role of Victor Carey in the deportations. ${ }^{45}$ Whether or not Luckhurst was correct in her assessment, this play provides an interesting litmus test for Guernsey 45 years after the island was liberated. 
Yet how did Bailhache manage to achieve so much - and apparently so easily - in contrast to the lack of progress on the memory of the Holocaust (as locally understood) in Guernsey? In order to understand this, we must examine the role of the "incremental memory event". Rather than having the power, in its own right, to "change how people remember, imagine, and talk about the past," 46 I argue that the incremental memory event acts instead to create punctures - smaller explosions - which can act to perforate previously impervious membranes of memory or taboo, thus facilitating the power of the eventual full memory event to create ruptures with previously accepted cultural meanings. In short, incremental memory events act to "soften up" its intended (or unintended) audience and to render them more receptive to memory events when they occur. I argue that memory events cannot or do not always achieve their effect or reach their true potential if people are not ready or willing to accept them as such. One might counter that a true memory event cannot be labelled as such if they lack such power or potential, but I do not contend that this is always the case, as I hope to argue here. While the impact of a memory event can be delayed, not always achieving its full potential at the time of its explosion, it can create a small tear (rather than a full rupture) in memory, which can be widened, made larger, and generally taken advantage of by the successful agent or author.

Between 1988 and 2001 there were a series of incremental memory events in Jersey that did not take place in Guernsey, thus making Bailhache's actions largely uncontroversial when they finally took place. Here I focus on heritage events, or incremental memory events that resulted in additions or changes to heritage relating to the Holocaust. Among these were the Anne Frank exhibition, which visited the island in 1988 and included a section on Jersey's Jews and Channel Islanders who were sent to concentration camps. This was judged to be the most popular exhibition ever to come to the island and was visited by over 15,000 islanders. In the mid-1990s, the leading member of Jersey's Jewish community, Freddie Cohen, found the very detailed lost wartime file relating to the island's Jews. At about the same time, Madeleine Bunting's book, The Model Occupation, was published. It is impossible to overstate the impact and outrage this book caused in the Channel Islands for its allegations of collaboration and downplaying of resistance, and perhaps it can be said to have caused something of a memory event in itself, but Guernsey's membrane remained impervious and her findings were rejected, denied and heavily criticised in both islands. The subject of collaboration was (and still remains more so in Guernsey than Jersey) highly taboo, and the book caused huge offence. It spurred Cohen to write an extended article for the Journal of Holocaust Education in 1997, which was later extended into a book in 2000, based on what he discovered in the archives. While Cohen felt that he had to be "reasonably careful" about how he presented his data so as not to be tarred with the same brush that was used on Bunting, his aims were to present the historical data so that the documents would "speak for themselves." responsibilities or to draw final conclusions"; rather, it was "to present the evidence now available ... as a source of information." 48

The data which Cohen collected was influential and compelling, even shocking, and the publication of his work was certainly an incremental memory event in itself. It laid bare the role of the islands' authorities for all to see, although the information from Guernsey's archives was far less detailed. As both president of the Jewish community at the time, and an agent of memory, Cohen organised a memorial service held at Jersey synagogue in 1998 in memory of the Jews who suffered in the Channel Islands. He revised the text of his journal paper for a volume to complement the service. The speakers included Sir Philip Bailhache, Sir Graham Dorey (then Bailiff of Guernsey); Jon Kay-Mouat, President of Alderney; and Lord Jakobovits, Emeritus Chief Rabbi, among others. A memorial to the island's Jews was unveiled as part of the service. 
Bailhache's involvement was considered to have been pivotal for the island as his address was the first occasion on which the suffering of the Jews in the Islands had been officially commemorated (http://www.occupationmemorial.com). Graham Dorey's speech was considered to have been brief and avoided any acknowledgement of culpability on the part of the island's authorities. Although the speeches were later uploaded onto the island's Occupation Memorial website, Dorey had meanwhile "lost his notes" and so the speech that he sent over months later was changed, ${ }^{49}$ and can be read online. It, too, is brief and entirely avoids pointing the finger of blame. Instead it briefly summarises the deportation of Guernsey's Jews. While there were only 150 people at the synagogue service, the event was heavily reported in the Jersey Evening Post and so the service became "pivotal in changing minds", as Cohen later put it me. ${ }^{50}$

Although Cohen's was not the only book on the Jews of the Channel Islands to be published in $2000,{ }^{51}$ his work had already made its impact over the previous few years and was on sale locally. Cohen was also a local man and his book was thus more likely to be read. It is worth noting that in order to make any sort of real or lasting impact, new books on the subject of the occupation often have to be accompanied by public lectures by the author and associated heritage initiatives such as exhibitions or memorial erections. This is hard for an outsider to achieve. Without this, new research which might make an impact among the academic community in the UK will receive only passing comment or interviews in the local papers, at best, in the Channel Islands. Bunting's book was an exception, and her allegations provoked local reactions in the heritage sphere, although not straight away. While it is hard to attribute direct cause and effect, post-1995 (the publication date of her book) heritage in Jersey, such as the Lighthouse Memorial (1996) and the forced worker memorial at La Hougue Bie (2001), was more inclusive of victims of Nazism. However, these were ushered in during the period of office of a Bailiff interested in this subject, and the directorship of Michael Day at Jersey Heritage, a man responsible for trying to counter the occupier-heavy heritage that the Channel Islands Occupation Society (CIOS) created in restored bunkers. As we have seen, Jersey had already started on a new and more inclusive trajectory before Bunting's book was published, so Bunting cannot claim to have single-handedly changed occupation heritage in the Channel Islands. ${ }^{52}$

In 1998, the first edition of historian Paul Sanders' book The Ultimate Sacrifice was published. This book detailed the stories of the "Jersey 22" (now known as the "Jersey 21" after one man, Walter Dauny, was recently found to have survived Villeneuve St George prison in Paris). With a foreword written by Bailhache, the book was seen as a "fitting adjunct" to the Lighthouse Memorial (so called because it used an old lighthouse in its design) unveiled by Bailhache in 1996. Less than two years later, Bailhache announced the establishment of Holocaust Memorial Day in the island and, from 2001 onwards, HMD has been commemorated annually in the island.

Both Guernsey and Jersey commemorated that first HMD with large crowds, and in Guernsey a small brass plaque was also erected at the harbour, in memory of the three deported Jewish women (figure 2). Guernsey's inter-faith ceremony was held in St James assembly hall in St Peter Port, but thereafter the event rapidly dwindled to become a small handful of people sometimes less than a dozen - clustered around the harbour plaque for a five minute outdoor ceremony held by a clergymen, with no member of the island's elite in attendance. In Jersey, the event has succeeded in attracting large crowds who fill the Tapestry Gallery of the island's maritime museum in St Helier. The tapestry tells the story of the German occupation in twelve panels and includes depictions of victims of Nazism in the form of forced and slave workers, and Canon Clifford Cohu who died in a concentration camp. The tapestry itself neglects the subject of the Jews, but the associated information panel recognises this group. The HMD ceremony includes guest speakers, speeches from leading members of the 
community, the involvement with the local youth theatre, and ends with floral wreaths being laid on the Lighthouse Memorial by community leaders ranging from the Lieutenant Governor, the Bailiff, the Constables ${ }^{53}$ of the island's parishes, the island's Dean, and other local elites.

INSERT HERE FIGURE 2: Caption: Jewish Memorial in Guernsey after the brief HMD ceremony in 2012. Copyright: Gilly Carr.

It is worth noting that in 2015 a thirteenth tapestry panel was commissioned, both as part of the $70^{\text {th }}$ anniversary of liberation celebrations, and as a way of recognising the changes in occupation memory and advances in research since the tapestry's unveiling in 1995 . The content of the new panel was conceptualised by the author, and honours those men and women who have acted as agents of memory in the field of heritage in Jersey, especially those who have brought about incremental memory events in relation to the island's victims of the Holocaust. The tapestry will feature Philip Bailhache, Harold Le Druillenec, former political prisoners, deportees and slave and forced workers, watching over the memorials that they instigated.

As we can see, Jersey positively reverberated with incremental memory events in the closing decade of the twentieth century, most of them safely ushered in by Philip Bailhache during this period as Bailiff, and only a few of which have been recounted here. Now in the twentyfirst century, Jersey is in a position to look back at what it has achieved in overcoming its old taboos. There have been no parallels in Guernsey. It is likely that Bailhache would not have been quite so successful in his endeavours as an instigator or agent of memory had he not been Bailiff. Such an office is held in high regard by islanders and is rarely criticised. A lowlier person, such as a member of the public with no public office or recognised authority, would probably have been largely ignored. As it is, Bailhache, aided by Cohen and Sanders (and even Bunting), punctured so many holes in the membrane of memory - in the Churchillian paradigm and the taboo against invoking the Holocaust - and provoked, instigated or supported so many Holocaust-related heritage initiatives, that combined, they and their endeavours ushered in an acceptance and embrace of the island's multiple victims of Nazism. The true memory event has taken place, but which of the incremental memory events achieved it would be hard to pin-point. Cumulatively, they have done their work.

Guernsey has had no parallel events - or rather, has rejected any of the elements which might have had the power to disturb or puncture the status quo (such as Bunting's book). It has had no Bailiff or other agent of memory prepared to usher in a period of self-reflection, criticism and acknowledgement of the potential sins of the grandfathers.

\section{Social Media and HMD 70 in the Channel Islands}

By the year before the $70^{\text {th }}$ anniversary of liberation, I had accumulated around one hundred testimonies written between 1964 and 1966 by Channel Islanders as part of their compensation claims, and had given a number of public lectures in the islands about them. I was thus asked to give the invited speech at Jersey's morning HMD 70 service, and collaborated with the organiser of Guernsey's HMD service - Deputy Elis Bebb, a Welshman who came to the island in the mid-1990s - to make the evening event in the island a success. I was interested to see whether I, as an outsider, could become an initiator (or co-initiator) of memory, using the reputation I had built up in the islands over eight years of heritage- and memory-related fieldwork. I wondered whether, if the focus was moved from Jews to locallyperceived co-sufferers of the Holocaust, Guernsey's guard would be down sufficiently for Guernsey's HMD 70 service to become a game-changing memory event through the public reading of testimonies of suffering in camps. 
A week before HMD, Elis Bebb had tweeted to advertise the HMD service and had contributed to an article on January 21, 2015, for the Guernsey Press where he spoke about how "the [local] authorities were responsible [for the deportation of three Jewish women] and therefore it's important that, as a community, we commemorate and remember that." Later, in the blog on his website, Bebb wrote that:

we in Guernsey deported the three Jewish women ... who were eventually murdered in Auschwitz ... we actively participated in the Holocaust ... the actions of the authorities in passing the anti-Semitic orders and those of the police in handing over people for deportation can only, in my opinion, be viewed as complicit (http://elisbebb.com/myViews/index.html, January 2015 archive).

Bebb had felt compelled to speak out because, as he wrote in the same blog article, he perceived that the "public narrative [of the occupation] has become too narrow." In short, Bebb had felt the power of the taboo in force in Guernsey and had tried to speak out against it by publicly pressing that most sensitive of buttons: a discussion of collaboration in the matter of the deportation of the Jews. His only saving grace was that he had not mentioned Carey; instead he used the word "we" in discussing responsibility. The social media backlash was swift, violent in its intensity, and led on Facebook by a local taxi driver, Neil Inder, who posted on various Facebook groups such as "Save the Guernseyman" and "Guernsey Days Gone By", using the headline banner of "Have you been offended?" He complained that Bebb was "being offensive", that his comments were "a sleight [sic] to all of those who endured the occupation", and that he was calling the people of Guernsey "Nazi sympathisers". Hundreds of people commented on Facebook, encouraged by interspersions by Inder, who added additional comments such as:

What Bebb is suggesting is that "we" as in "all" Guernsey people under Occupation actively participated and contributed to the Holocaust. Anyone with an Occupation history - we all have them - evacuated, starved, fought and died, should find wholly offensive" (January 19, 2015, Facebook comment).

Inder and other islanders called (without a trace of irony) for Bebb to be removed from his position and deported. Popular opinion was in full support of the local authorities who "did their best" during the occupation. They rejected the notion that "Guernsey participated in the Holocaust", believed that the subject "does not need to be investigated" and that unless Bebb was there at the time, he had no right to judge. There were a few dissenting voices, although they were silenced by the majority. Inder then filed a "Code of Conduct" in the Royal Court against Bebb a couple of days later. The Code regulates the "duties, standards, propriety and conduct, in public life", of the Deputies of the Royal Court, ${ }^{54}$ and Inder felt that Ebb had breached it.

His letter to the chairman of the States Members' Conduct Panel, which he wrote and uploaded to Facebook on January 22, 2015, argued that "by accusing Islanders of participating in the Holocaust he ... continues to bear false witness against Islanders by directly accusing the population as participants"; that he had "abused his position as Deputy and member of St Peter Port Church in the organisation of the [HMD] interdenominational service"; that he had "brought the Island's name into disrepute by adding our Island's name to countries that "participated in the Holocaust"; and that he was "using the Holocaust Day Service to push his own view of the history of the Island". Inder's complaint was rejected on the grounds that it was not a function of the Code of Conduct Panel to be the arbiter between 
people who happen to hold strongly different opinions, and this rejection letter was also uploaded to the Facebook thread the following day.

This vitriolic exchange highlighted to me not only the strength of the "Carey effect", which prevented Bailiffs and others in high office from speaking out, but the strength of the taboo which unwitting non-local islanders could stumble into (even if they had joined the elite of local government), and which islanders from all walks of life would take swift and strong measures to uphold. The impermeable membrane of memory in Guernsey was tougher than I imaged and, having collaborated with Bebb in the organisation of the HMD service, we both wondered whether anyone would attend, or whether the church would be boycotted and picketed by islanders holding placards. Not only had the incremental memory events in Jersey (including the publication of Freddie Cohen's authoritative book on the Jews of the Channel Islands) had no impact at all in Guernsey, where Facebook comments suggested that nobody had read Cohen's book, but I realised that forcing or creating an incremental memory event was going to be very difficult indeed.

On January 27 I delivered my speech about the experience of Channel Islanders in Nazi prisons and concentration camps at the HMD 70 ceremony in Jersey. Discussions with a number of people indicated that they were watching the social media row (which had spilled over into the local paper and radio) in their sister island with a mixture of disbelief and amusement. Having passed through this phase in discussing occupation wrongdoings twenty years earlier, they hoped that this incident would help Guernsey go through the same process. Later that day, after flying to Guernsey, I was one of the first to arrive at the town church in St Peter Port. To my surprise, the church slowly filled to capacity and no one was waiting outside with placards. In the event, and for the first time, many more people attended the HMD service in Guernsey than in Jersey; even the Bailiff and Chief Minister were there. Last to arrive was Sir de Vic Carey, who made his way to the back of the church before the current Bailiff, Sir Richard Collas, invited him to sit at the front, next to him.

During the service, three children and one grandchild of Guernseymen who had experienced Nazi camps read out the testimonies written by their family member fifty years earlier (figure 3). The effect was electrifying, and the gasps and shocked silence in the church made it clear that this was entirely new to islanders. At this point, the service seemed to develop a life of its own. By the end, it appeared that Deputy Bebb had pulled off a coup and silenced his detractors. Later that evening, Bebb posted a comment on his Facebook page which summed up the mood:

I have no idea what I was involved in this evening. But this I know, Guernsey stood as a testament to how the Holocaust happened to people who lived here ... And those testimonies brought us together as a whole community to mark the day and remember the horror.

Sir de Vic even sent a supportive email to Bebb and me to say that he found the service "a very moving and thoughtful occasion [which] widened the local experience of suffering at the hands of the Nazis ... the reading of the testimonies in this way was long overdue."

INSERT FIGURE 3 here: Caption: Peter Symes reading out his father's testimony about Buchenwald, HMD 2015, Guernsey. Copyright: Gilly Carr

The following day, the social media sites, which had been so full of bile just a day previously, fell silent. The Guernsey Press gave the event full coverage on January 28, and showed a picture of Paul Domaille giving the testimony of his father's forced march towards Dachau. It seemed that those on social media had been outvoted by other islanders, and the testimonies 
had brought home to people precisely how the ordinary people of Guernsey had been involved in the Holocaust.

On January 31, my full page article entitled "The night the Holocaust came home" was published in the Guernsey Press. In it, I discussed how the Holocaust affected the island; how Channel Islanders had experienced the darkest and most evil centres of killing; and how the toxic social media debate had revealed that the best legacy that HMD 70 could leave the island would be "education of the young and the provision of accurate and locallymeaningful teaching materials." But had Guernsey's membrane of memory been perforated during the furore of January 2015?

\section{Conclusion}

The number of incremental memory events in Jersey over the last twenty to twenty-five years has resulted in an island that is now comfortable in its own skin. The pre-existing taboos were broken during Bailhache's period of office as Bailiff and in the years before. Five years ago the island was even involved in putting forward successfully the names of four islanders for the British "Hero of the Holocaust" award (as mentioned on the BBC website for March 9, 2010, http://news.bbc.co.uk/1/hi/uk/8558739.stm).

Guernsey, on the other hand, has lacked similar incremental memory events until much more recently, and has shown itself to have acquired a largely impervious membrane of memory when it comes to historical taboos. It has thus been instructive to examine the events of 2015 in this island. I have suggested here that we may have witnessed several incremental memory events in 2015; small explosions which succeeded in making some small yet significant punctures in that tough membrane at last in a way that various publications on the occupation over the last 20 years have been unable to achieve. Until cemented through heritage or accompanied by heritage events, and preferably endorsed by public elites, new research alone doesn't always make the desired impact.

The toxic debate on social media following the suggestion made by a Guernsey politician that the island had a role to play in the Holocaust resulted in an explosion in all of the island's media. This in itself resulted in an utterly unexpected show of feeling reflected in the packed town church on HMD 70 in St Peter Port, where the testimonies of Nazi persecution were heard for the first time in public.

That these events had reverberated in Guernsey was again demonstrated by Sir de Vic Carey being invited in April 2015 to give a public lecture about his late grandfather. Sir de Vic has long been notoriously reticent about speaking about his grandfather, but was persuaded to "put the record straight" as the Guernsey Press put it afterwards, in an article on May 1, 2015. In the lecture, he complained the Victor Carey had been "badly treated by posterity" and stated that he regretted "the ongoing negativity and criticism of those who were doing their honest best for the island's people ..." Sir de Vic was, it seems, commenting on the furore of three months earlier.

In early May 2015, a resistance memorial was unveiled at the harbour in St Peter Port by the current Bailiff, and I was asked again to give a speech recounting the stories of the "Guernsey 8" who died in Nazi prisons and camps. The event was attended by large crowds - even Sir de Vic Carey was spotted standing on the sidelines - and the Bailiff had been persuaded to hold a Vin d'Honneur for the families of the Guernsey 8 afterwards. This was something that I had personally requested as part of a move to facilitate the acceptance of resisters into the local understandings of the Holocaust through elite support. I followed up the day with another article to the Guernsey Press (May 21, 2015), with the intention of cementing a new understanding of these "trouble makers" who "stepped out of line with the Germans."

There are wider issues to consider here about the role of academics as activists, and I have never been reticent in the Channel Islands about my support of victims of Nazi persecution; 
indeed, this is why I have been asked to give public lectures and speeches on many occasions. Even when academics act as activists, however, they cannot assume that they will be listened to or accepted; sometimes they need to find their moment to act, or let the acts of the moment find them.

The main focus of this paper, however, was to explore local understandings of and long-term attitudes towards the Holocaust and to seek to understand how the taboo was punctured in Jersey. Through identifying the active role of incremental memory events in that island, and its solidification through heritage, I have sought to understand Guernsey's ongoing impervious memory membrane and to identify whether the events leading up to and following HMD 70 will themselves prove to have succeeded in making punctures at last.

Perhaps we will not always identify an incremental memory event when we see it; it may be that only a sustained and ongoing attack on tightly held taboos will reveal itself to have been successful in the long run. Perhaps we might better understand some of these events as "delayed memory events"; sometimes the reverberations take time to fully play out. In any case, it is likely that the final incremental memory event which causes the large tear along the perforations of the memory membrane in Guernsey will be the moment when Victory Carey's grandson departs the stage. Guernsey's occupation Bailiff left no diaries or memoirs, and Sir de Vic is the one person who can provide us with an insight into his grandfather's psyche and actions. However, the day is approaching when Guernsey will lose its reputation as the last place in Europe to have never discussed publicly its role in the Holocaust.

\section{Acknowledgements}

The author would like to thank Freddie Cohen, Elis Bebb, Sir de Vic Carey and Sir Philip Bailhache for interviews collected during fieldwork. I would also like to thank the Holocaust Memorial Day committee in Jersey for inviting me to the island to speak at the HMD 70. While writing about the taboo in Guernsey in itself breaks taboos, I hope that any Channel Islander will recognise this paper as an accurate and faithful reflection and interpretation of the events of the last 70 years, and most especially of 2015.

\section{Bibliography}

Bar-On, Dan. Fear and Hope: Three Generations of the Holocaust. Cambridge, MA: Harvard University Press, 1995.

Berger, Stefan. "Remembering the Second World War in Western Europe, 1945-2005." In A European Memory? Contested Histories and Politics of Remembrance, edited by Małgorzata Pakier and Bo Stråth, 119-136. New York and Oxford: Berghahn Books, 2010.

Bunting, Madeleine. The Model Occupation: The Channel Islands under German Rule, 19401945. London: BCA / HarperCollins, 1995.

Carr, Gilly. Testimonies of Nazi Persecution from the Channel Islands: A Legitimate Heritage? London: Bloomsbury Academic, forthcoming.

Carr, Gilly. 2015a. "Mum of a Nazi Victim. Did you know Charlotte Ashcroft?" Guernsey Press, January 17.

Carr, Gilly. 2015b. "Remembering those Absent Friends." Guernsey Press, May 21.

Carr, Gilly. 2014a. "Help me Tell Brave Islanders' Stories.” Guernsey Press, August 15. 
Carr, Gilly. Legacies of Occupation: Heritage, Memory and Archaeology in the Channel Islands. New York: Springer, 2014b.

Carr, Gilly. 2013. "Stories of Suffering under the Nazis." Jersey Evening Post, July 11, 2013.

Carr, Gilly, Paul Sanders, and Louise Willmot. Protest, Defiance and Resistance in the Channel Islands: German Occupation 1940-1945. London: Bloomsbury Academic, 2014.

Cohen, Frederick. The Jews in the Channel Islands during the German Occupation 19401945. Jersey: Jersey Heritage Trust, 2000.

Connelly, Mark. "We Can Take It! Britain and the Memory of the Home Front in the Second World War." In Experience and Memory: The Second World War in Europe, edited by Jorg Echternkamp and Stefan Martens, 53-69. New York and Oxford: Berghahn Books, 2010.

Cruikshank, Charles. The German Occupation of the Channel Islands. Oxford: Oxford University Press, 1975 and Guernsey: The Guernsey Press. Reprint, Stroud: Sutton Publishing, 2010. Page references are to the 2010 edition.

Etkind, Alexander. "Mapping Memory Events in the East European Space." East European Memory Studies 1 (2010): 4-5.

Falla, Frank. The Silent War. London: Leslie Frewin, 1967. Reprint, Guernsey: Burbridge Ltd, 1994. Page references are to the 1994 edition.

Fraser, David. The Jews of the Channel Islands and the Rule of Law, 1940-1945. Brighton: Sussex Academic Press, 2000.

Ginns, Michael. The Organisation Todt and the Fortress Engineers in the Channel Islands. Jersey: Channel Islands Occupation Society Archive Book No. 8, 2006.

Luckhurst, Mary. "The Case of Theresa: Guernsey, the Holocaust, and Theatre Censorship in the 1990s." European Studies 17 (2001): 255-267.

Miere, Joe. 2004. Never to be Forgotten. Jersey: Channel Island Publishing.

Ramsden, John. "Myths and Realities of the 'People's War' in Britain." In Experience and Memory: The Second World War in Europe, edited by Jorg Echternkamp and Stefan Martens, 40-52. New York and Oxford: Berghahn Books, 2010.

Rousso, Henri. "History of Memory, Policies of the Past: What for?" In Conflicted Memories: Europeanizing Contemporary Histories, edited by Konrad Jarausch and Thomas Lindenberger, 23-77. New York: Berghahn Books, 2007.

Sanders, Paul. "Narratives of Britishness: UK War Memory and Channel Islands Occupation Memory." In Islands and Britishness: A Global Perspective, edited by Jodie Matthews and Daniel Travers, 24-39. Newcastle Upon Tyne: Cambridge Scholars Publishing, 2012.

Sanders, Paul. The Ultimate Sacrifice. Jersey: Jersey Heritage Trust, 2004. 
Sanders, Paul. The British Channel Islands under German Occupation, 1940-1945. Jersey: Société Jersiaise and Jersey Heritage Trust, 2005.

States of Guernsey, Code of Conduct for States Members. http://www.gov.gg/codeofconductforstatesmembers.

Sherwill, Ambrose. A Fair and Honest Book: The Memoirs of Ambrose Sherwill. Lulu.com, 2006.

Wieviorka, Annette. The Era of the Witness. Ithaca and London: Cornell University Press, 2006.

Willmot, Louise. "Humanitarian Resistance: Help to Jews and OT workers." In Protest, Defiance and Resistance in the Channel Islands: German Occupation 1940-1945, by Gilly Carr, Paul Sanders and Louise Willmot, 97-126. London: Bloomsbury Academic, 2014.

Winter, Jay. "Forms of Kinship and Remembrance in the Aftermath of the Great War." In War and Remembrance in the Twentieth Century, edited by Jay Winter and Emmanuel Sivan, 40-60. Cambridge: Cambridge University Press, 1999.

Wood, Alan, and Mary Wood. Islands in Danger. New York: Macmillan Company, 1955.

\section{Notes}

${ }^{1}$ Etkind, Mapping Memory Events in the East European Space.

2 Berger, "Remembering the Second World War in Western Europe, 1945-2005," 128-9.

${ }^{3}$ Cohen, The Jews in the Channel Islands.

${ }^{4}$ Carr et al, Protest, Defiance and Resistance.

${ }^{5}$ Ginns, The Organisation Todt.

${ }^{6}$ Sanders, "Narratives of Britishness: UK War Memory and Channel Islands Occupation Memory," 25.

${ }^{7}$ Sanders, The British Channel Islands, 256.

${ }^{8}$ Ramsden, "Myths and Realities of the 'People's War' in Britain," 40.

${ }^{9}$ Connelly, "We Can Take It! Britain and the Memory of the Home Front in the Second World War," 54.

${ }^{10}$ Sanders, "Narratives of Britishness: UK War Memory and Channel Islands Occupation Memory," 26.

${ }^{11}$ Ibid., 36.

${ }^{12}$ Cruikshank, The German Occupation, $204 \& 217$.

${ }^{13}$ Cohen, The Jews in the Channel Islands, 124.

${ }^{14}$ Ibid., 62.

${ }^{15}$ Sanders, The Ultimate Sacrifice, 90-93.

${ }^{16}$ Cohen, The Jews in the Channel Islands, 13-14.

${ }^{17}$ Ibid.

${ }^{18}$ Ibid., 18-43.

19 The office of Bailiff is specific to the Channel Islands and is a crown appointment. The Bailiff is the presiding officer or chief justice of the Royal Court and presides over the local parliament - the States of Deliberation (Guernsey) or States Assembly (Jersey). 
${ }^{20}$ In Guernsey the Jurats, as lay people, are judges of fact rather than law. They are representatives of the island parishes. As there is no jury service in Guernsey, the Jurats act as the jury. They are members of the Royal Court.

${ }^{21}$ Sherwill, A Fair and Honest Book, 234.

${ }^{22}$ Cohen, The Jews in the Channel Islands, 33.

${ }^{23}$ Willmot, "Humanitarian Resistance: Help to Jews and OT Workers," 197; Salvation Army International Heritage Centre Personality Files: Marie Ozanne. Letter from Major Marie Ozanne to the Feldkommandant, Guernsey, 26 June 1941.

${ }^{24}$ An English Heritage initiative whereby plaques are attached to houses to remember famous former inhabitants.

${ }^{25}$ Cohen, The Jews in the Channel Islands, 50.

${ }^{26}$ Priaulx Library, Guernsey, ref. LF940.53, Rev. Douglas Ord Occupation Diary.

${ }^{27}$ Carr et al., Protest, Defiance and Resistance, 351.

${ }^{28}$ Miere, Never to be Forgotten, 300-314; http://www.thisisjersey.co.uk/hmd/html/570.html.

${ }^{29}$ Falla, The Silent War, 166.

${ }^{30}$ Carr, Testimonies of Nazi Persecution.

${ }^{31}$ Bar-On, Fear and Hope.

${ }^{32}$ Bunting, The Model Occupation, 77.

${ }^{33}$ Sherwill, A Fair and Honest Book, 140.

${ }^{34}$ Wood and Wood, Islands in Danger, 236-7.

${ }^{35}$ The National Archives FO 950/740. Circular no. 97, dated July 31, 1964.

${ }^{36}$ Falla, The Silent War, 161-2.

${ }^{37}$ Ibid., 167.

${ }^{38}$ Etkind, "Mapping Memory Events in the East European Space," 4-5.

${ }^{39}$ Winter, "Forms of Kinship and Remembrance in the Aftermath of the Great War," 40.

${ }^{40}$ Falla, The Silent War, 167.

${ }^{41}$ Wieviorka, The Era of the Witness, 88.

${ }^{42}$ Ibid., 57 \& 87.

${ }^{43}$ Carr, Legacies of Occupation, 289.

${ }^{44}$ Rousso, "History of Memory, Policies of the Past: What for?", 207.

${ }^{45}$ Luckhurst, "The Case of Theresa: Guernsey, the Holocaust, and Theatre Censorship in the 1990 s," 255 \& 262.

${ }^{46}$ Etkind, "Mapping Memory Events in the East European Space," 5.

${ }^{47}$ Telephone interview with Freddie Cohen, 5 February 2015.

${ }^{48}$ Cohen, The Jews in the Channel Islands, 11.

${ }^{49}$ Telephone interview with Freddie Cohen, 5 February 2015.

${ }^{50}$ Ibid.

${ }^{51}$ Fraser, The Jews of the Channel Islands and the Rule of Law.

${ }^{52}$ Carr, Legacies of Occupation, 108-9.

${ }^{53}$ The Constable (or Connétable) is the elected head of a parish in the Channel Islands.

54 States of Guernsey. 'Code of Conduct for States Members'. http://www.gov.gg/codeofconductforstatesmembers. 